\title{
PENINGKATAN KETERAMPILAN GURU IPS SMP DALAM PENGGUNAAN SISTEM INFORMASI GEOGRAFIS UNTUK MEWUJUDKAN KURIKULUM 2013 DI KOTA BENGKULU
}

\author{
Endina Putri Purwandari ${ }^{1}$, Desi Andreswari ${ }^{2}$ \\ ${ }^{1,2}$ Program Studi Teknik Informatika, Fakultas Teknik \\ Universitas Bengkulu, Bengkulu \\ ${ }^{1}$ endinaputri@unib.ac.id \\ 2d_andrez@gmail.com
}

\begin{abstract}
Abstrak: Pada Kurikulum 2013, bidang ilmu Geografi dipakai sebagai landasan (platform) pembahasan dalam pembelajaran IPS Terpadu di SMP. Penghapusan pelajaran TIK berdampak langsung terhadap mata pelajaran di SMP. Namun pada kenyataannya guru IPS SMP di Kota Bengkulu belum memiliki kemampuan dan pengetahuan TIK yang memadai. Kegiatan ini melibatkan Kelompok MGMP Guru IPS se-Kota Bengkulu berjumlah 35 orang yang merupakan perwakilan dari 24 SMP Negeri/SMP Swasta/MTs. Fokus kegiatan pada peningkatan kemampuan dan motivasi guru-guru IPS dalam menguasai perangkat, dan media TIK dalam pembelajaran IPS, serta aplikasi SIG dengan program Google Earth. Pada akhir kegiatan guru-guru telah menunjukkan perubahan penguasaan teori SIG dari level kognitif pemahaman menjadi level penerapan. Perangkat SIG ini mendukung pembelajaran yang berpusat pada siswa dan berpusat pada pengetahuan. Melalui kegiatan ini telah dapat meningkatkan kemampuan guru IPS SMP se-Kota Bengkulu untuk (1) mengintegrasikan mata pelajaran IPS dengan TIK untuk implementasi Kurikulum 2013; (2) menyusun modul belajar yang mengintegrasikan perangkat, media TIK, dan aplikasi SIG dengan kompetensi mata pelajaran IPS SMP; dan (3) meningkatkan kapasitas guru IPS SMP di Kota Bengkulu dalam membaca, memahami, dan menggunakan peta geografis elektronik online Google Earth. Potensi penggunaan TIK dapat maksimal bila didukung keterampilan teknis dan keterampilan perencanaan pembelajaran dari guru IPS SMP.

Kata kunci: Sistem Informasi Geografis, Google Earth, Ilmu Pengetahuan Sosial, SMP, TIK
\end{abstract}

\begin{abstract}
In the 2013 curriculum, Geography used as a platform for Integrated Social Science learning in junior high school. ICT elimination give direct impact for the lesson in junior high school. But social teacher in junior high school doesn't have enough ICT ability and knowledge. This activity involves MGMP as a Social Teacher Group in the Bengkulu city amounted to 35 people that consist of 24 junior high school from public and private school. Focus activities on improving the ability and motivation of social teachers in mastering ICT device and media in learning social studies, as well as the GIS application like Google Earth. At the end of activities, teachers have shown mastery of GIS theory understanding changes in cognitive level to the application level. GIS devices support student-centered learning and knowledge
\end{abstract}

centered. Through this activity has been able to increase the ability of social studies teacher at Bengkulu City to (1) integrate social studies with ICT for the implementation of Curriculum 2013; (2) develop learning modules that integrate devices, ICT media, and GIS application with social studies competency; and (3) increase the social studies capacity for teacher in the Bengkulu city in reading, understanding, and using the electronic geographical maps online like Google Earth. ICT potential use can be maximized when supported technical and planning skills from social studies teacher in junior high school.

Keywords: GIS, Google Earth, Social Sciences, Junior High School, ICT 


\section{PENDAHULUAN}

Geografi adalah ilmu yang mempelajari permukaan bumi dengan menggunakan pendekatan keruangan, ekologi, dan kompleks wilayah [1]. Pada Kurikulum 2013, bidang ilmu Geografi dipakai sebagai landasan (platform) pembahasan bidang ilmu yang lain. Melalui gambaran umum tentang wilayah Negara Kesatuan Republik Indonesia (NKRI), dikenalkan keberagaman potensi masing-masing daerah. Pengetahuan dan keterampilan yang dibangun melalui tugas individu dan kelompok diupayakan kontekstual yaitu dikaitkan objek atau fenomena yang ada di sekitar peserta didik sampai lingkup regional (propinsi, kabupaten/kota). Kurikulum 2013 dirancang untuk memperkuat kompetensi siswa dari sisi sikap, pengetahuan, dan keterampilan secara utuh.

Mata pelajaran TIK telah dihapus dari Kurikulum 2013, namun diintegrasikan dengan semua mata pelajaran. Artinya setiap guru pelajaran wajib memiliki keahlian dalam menggunakan perangkat dan media TIK. Namun, dengan perubahan ini tidak semua sekolah memiliki guru mata pelajaran yang juga menguasai perangkat dan media TIK. Kemampuan dan pengetahuan guru IPS SMP di Kota Bengkulu masih sangat perlu dilatih untuk pemanfaatan dan pemahaman aplikasi teknologi informasi yang dapat mendukung proses belajar-mengajar. Oleh karena itu, sangat diperlukan kegiatan yang dapat memberikan pengetahuan Sistem Informasi Geografis (SIG) dan mengintegrasikan pelajaran dengan perangkat, media, dan teknologi TIK untuk mewujudkan implementasi kurikulum 2013 bagi Guru IPS SMP di Kota Bengkulu.

Rumusan permasalahan dalam kegiatan ini, sebagai berikut:
1. Bagaimana meningkatkan pemahaman guru IPS SMP di Kota Bengkulu untuk mengintegrasikan mata pelajaran IPS dengan TIK dalam rangka implementasi Kurikulum 2013

2. Bagaimana menyusun modul belajar yang mengintegrasikan perangkat, media, dan aplikasi TIK dengan kompetensi mata pelajaran IPS SMP.

3. Bagaimana meningkatkan kapasitas guru IPS SMP di Kota Bengkulu dalam membaca dan memahami peta geografis elektronik online Google Earth.

Kegiatan ini melibatkan MGMP Guru IPS seKota Bengkulu berjumlah 35 orang, yang merupakan perwakilan dari 24 SMP Negeri, SMP Swasta, dan MTs se-Kota Bengkulu. Fokus kegiatan adalah pada peningkatan kemampuan dan motivasi guru-guru IPS dalam menguasai perangkat, dan media TIK dalam pembelajaran IPS, serta aplikasi SIG dengan program Google Earth.

\section{LANDASAN TEORI}

\section{A. Sistem Informasi Geografis (SIG) mewujudkan} Implementasi Kurikulum 2013

Sistem Informasi Geografis (SIG) menurut ESRI [2] mendefinisikan SIG sebagai kumpulan yang terorganisir dari perangkat keras computer, perangkat lunak, data geografi dan personil yang didesain untuk memperoleh, menyimpan, memperbaiki, memanipulasi, menganalisis dan menampilkan semua bentuk informasi yang bereferensi geografis. SIG dapat merepresentasikan model real world (dunia nyata) di atas monitor komputer. Peta merupakan salah satu bentuk representasi grafis dunia nyata. SIG memiliki keunggulan karena penyimpanan data 
(basis data spasial) dan presentasi dalam berbagai cara dan bentuk yang dinamis [3].

Kurikulum 2013 dirancang untuk memperkuat kompetensi siswa dari sisi pengetahuan, keterampilan dan sikap secara utuh. Kemdikbud [4] menyusun Ilmu Pengetahuan Sosial (IPS) dikembangkan secara terpadu, tidak dipisah dalam kelompok geografi, sejarah, ekonomi, dan sosiologi. Pada buku IPS Kelas VII SMP/MTs [4], bidang ilmu Geografi dipakai sebagai landasan (platform) pembahasan bidang ilmu yang lain. Melalui gambaran umum tentang wilayah Negara Kesatuan Republik Indonesia (NKRI), dikenalkan keberagaman potensi masingmasing daerah. Dalam pelaksanaan kegiatan pembelajarannya, peserta didik lebih diarahkan untuk memiliki kemampuan berpikir, kemampuan belajar, rasa ingin tahu, dan pengembangan sikap peduli dan bertanggung jawab terhadap lingkungannya [5].

Penggunaan perangkat, dan media SIG, serta aplikasi Google Earth dapat memberi kesan yang mendalam pada pelajar SMP. Aplikasi Google Earth merupakan aplikasi atau program Globe Virtual yang dapat melihat seluruh dunia atau diibaratkan kita menjadi seorang penjelajah atau angasawan yang mampu menjelajahi alam semesta dalam waktu singkat [6]. Dengan aplikasi ini, pelajar mampu mengelilingi seluruh dunia, menjelajah daerah-daerah di sekitarnya, dan menampilkan foto satelit secara 3 dimensi (3D).

Tabel 1. Mata Pelajaran Sekolah Menengah Pertama/Madrasah Tsanawiyah

\begin{tabular}{|c|c|c|c|c|}
\hline \multirow{2}{*}{\multicolumn{2}{|c|}{ MATA PELAJARAN }} & \multicolumn{3}{|c|}{$\begin{array}{c}\text { ALOKASI WAKTU PER } \\
\text { MINGGU }\end{array}$} \\
\hline & & VII & VIII & IX \\
\hline \multicolumn{5}{|c|}{ Kelompok A } \\
\hline 1. & Pendidikan Agama dan Budi Pekerti & 3 & 3 & 3 \\
\hline 2. & Pendidikan Pancasila dan Kewarganegaraan & 3 & 3 & 3 \\
\hline 3. & Bahasa Indonesia & 6 & 6 & 6 \\
\hline 4. & Matematika & 5 & 5 & 5 \\
\hline 5. & Ilmu Pengetahuan Alam & 5 & 5 & 5 \\
\hline 6. & Ilmu Pengetahuan Sosial & 4 & 4 & 4 \\
\hline & Bahasa Inggris & 4 & 4 & 4 \\
\hline \multicolumn{5}{|c|}{ Kelompok B } \\
\hline 1. & Seni Budaya & 3 & 3 & 3 \\
\hline 2. & Pendidikan Jasmani, Olah Raga, dan Kesehatan & 3 & 3 & 3 \\
\hline 3. & Prakarya & 2 & 2 & 2 \\
\hline & JUMLAH ALOKASI WAKTU PER MINGGU & 38 & 38 & 38 \\
\hline
\end{tabular}

pelajaran Teknologi Informasi dan Komunikasi (TIK) telah dihapuskan. Konsep Kurikulum 2013 adalah membangun pengetahuan dan pembelajaran yang membuat siswa terampil menguasai konsep secara konkret dan abstrak. Dengan perangkat media TIK dalam pembelajaran IPS, serta aplikasi SIG program Google Earth ini membuat siswa menjadi lebih aktif karena sifat ingin tahu mereka yang sangat tinggi dalam proses pengajaran dan pembelajaran [6]. Peran guru sangat penting untuk meningkatkan dan menyesuaikan daya serap siswa. Cara pengemasan pengalaman belajar yang dirancang guru sangat berpengaruh terhadap kebermaknaan pengalaman bagi siswa.

Berdasarkan analisis situasi dan tinjauan pustaka di atas, maka tujuan umum kegiatan ini adalah untuk memberikan keterampilan kepada guru SMP dalam interpretasi peta dan dapat menyusun serta menampilkan informasi geospasial di daerahnya. Sehingga diharapkan guru dapat: (1) mengetahui cara mengintegrasikan perangkat, media, dan aplikasi TIK dengan mata pelajaran IPS SMP; (2) memahami cara menggunakan dan membaca Virtual Globe dengan aplikasi Google Earth; (3) mampu mengkaitkan informasi pada peta dengan karakteristik potensi dan budaya lokal daerah; dan (4) menerapkan setiap kompetensi dan unsur-unsur pengajaran IPS yang berorientasikan TIK untuk meningkatkan pemahaman dan meningkatkan kebermaknaan pengalaman peserta didik. Ketercapaian tujuan kegiatan ini dapat berdampak pada peningkatan mutu pembelajaran IPS SMP di Kota Bengkulu.

\section{METODE PENELITIAN}

Metode kegiatan berupa pelatihan pada guruguru SMP se-Kota Bengkulu. Guru diberikan pembimbingan untuk mengeksplorasi program dan 
menggunakan aplikasi TIK, SIG untuk memungkinkan guru-guru menggali pengetahuan mewujudkan implementasi kurikulum 2013. sebanyak-banyaknya tentang aplikasi TIK dan SIG Tahapan-tahapan yang dilakukan adalah sebagai yang mendukung proses belajar mengajar IPS. berikut:

\section{A. Tahap Persiapan}

Tahap persiapan yang dilakukan meliputi: (a) Survei; (b) Pemantapan dan penentuan lokasi sasaran; (c) Penyusunan bahan/materi pelatihan, yang meliputi: makalah dan modul, peta geografis Propinsi Bengkulu, peta potensi lokal Bengkulu, dan peta karakteristik Bengkulu.

\section{B. Tahap Pelaksanaan}

Pada tahap ini dilakukan penjelasan mengenai penggunaan SIG dalam mata pelajaran IPS. Sesi pertama, berfokus pada metode ceramah untuk memberikan penjelasan mengenai cara membaca peta SIG, menggunakan aplikasi Google Earth, mengkaitkan informasi SIG yang diperoleh dengan karakteristik potensi dan budaya lokal Propinsi Bengkulu.

Sesi kedua, menitikberatkan pada kemampuan guru tentang (1) mengidentifikasi, memilih, dan merumuskan informasi SIG ke dalam kompetensi mata pelajaran IPS di setiap tatap muka kelas, (2) menyusun kerangka pembelajaran; (3) mengumpulkan bahan-bahan peta dan informasi potensi sumber daya alam, potensi sumber daya manusia, sebaran kebudayaan, potensi pariwisata di Kota Bengkulu; dan (4) menuliskan informasi SIG tersebut sesuai dengan kompetensi dasar mata pelajaran IPS. Sehingga siswa memperoleh pengalaman belajar yang utuh dan terpadu tentang pelajaran IPS dan implementasinya dalam TIK untuk mewujudkan implementasi kurikulum 2013.

Selanjutnya, kegiatan tanya jawab (Focus Group Discusion) sangat penting bagi peserta baik ketika menerima penjelasan tentang aplikasi SIG serta saat mempraktikkannya. Metode ini

\section{HASIL DAN PEMBAHASAN}

Penggunaan aplikasi SIG merupakan bagian mutlak dari pelaksanaan pembelajaran berbasis kompetensi. Kompetensi adalah sekumpulan pengetahuan, ketrampilan, sikap, dan nilai sebagai kinerja yang berpengaruh terhadap peran, perbuatan, prestasi, serta pekerjaan seseorang [4]. Pengetahuan merupakan pengetahuan tentang fakta atau prosedur. Ketrampilan adalah keterampilan kognitif atau perilaku sedangkan karakteristik personal adalah ciri pembawaan individu. Pada masing-masing kompetensi terdapat tuntutan untuk membentuk tiga golongan ranah, yaitu kognitif, afektif, dan psikomotorik. Hal ini dilakukan dengan berbagai alat dan media pembelajaran sebagaimana yang ada pada Geografi. Kompetensi pada Geografi mutlak membutuhkan berbagai alat peraga terutama yang berkaitan peta dan citra, baik yang sifatnya hasil fotografik maupun satelit atau peta digital.

Pembelajaran IPS pada tingkat SMP/MTs dalam kurikulum 2013diarahkan pada 3 (tiga) sasaran, yaitu (1) menganalisis gejala alam fisik dan perkembangan bentuk muka bumi serta pelestariannya; (2) mengevaluasi gejala sosial di muka bumi beserta interaksinya dan pengaruhnya dalam kehidupan, dan (3) menggunakan konsep wilayah dalam memahami lokasi, pola, penyebaran, dan hubungan antar obyek. Pada akhir kegiatan guru-guru telah menunjukkan perubahan penguasaan teori SIG dari level kognitif pemahaman menjadi level penerapan.

Kegiatan ini memberikan kesempatan peserta secara langsung mempratikkan dan mencoba 
mengoperasikan perangkat komponen Sistem Informasi Geografi (SIG), baik perangkat keras maupun lunak. Hasil kegiatan yang telah dicapai, yaitu:

(1) Analisis standar kompetensi dengan melakukan pemetaan Kompetensi Inti (KI) dan Kompetensi Dasar (KD) yang diturunkan dari setiap Tema Pembelajaran untuk kelas 7 dan kelas 8 SMP berdasarkan Kurikulum 2013. Analisis ini bertujuan untuk menyusun dan menetapkan materi-materi yang dapat dijelaskan atau diperagakan dengan menggunakan SIG dan program aplikasi Google Earth.

(2) Studi pendahuluan dan sosialisasi kegiatan pada saat Rapat Tim MGMP se-Kota Bengkulu untuk mengetahui jumlah peserta dan tingkat kemampuan atau wawasan peserta mengenai SIG dan Google Earth.

(3) Kisi-kisi instrumen kegiatan SIG yang mengacu pada analisis standar kompetensi Kurikulum 2013 mata pelajaran IPS SMP.

(4) Modul SIG berupa petunjuk praktis penggunaan program Google Earth yang sudah disesuaikan dengan standar kompetensi Kurikulum 2013 mata pelajaran IPS SMP.

(5) Media berupa peta-peta pendukung pembelajaran dan CD program aplikasi. Pada CD tersebut berisi seluruh materi pelatihan SIG, modul penggunaan program Google Earth, installer program Google Earth, petunjuk praktis cara meng-install, dan softcopy peta-peta pendukung.

Tahapan-tahapan dalam kegiatan ini adalah fase retensi, reproduksi, dan motivasi. Pada fase retensi akan dilakukan penyajian materi pelatihan, dan analisis KD IPS pada kurikulum 2013 yang sudah dilengkapi dengan materi ICT SIG, serta tutorial cara menggunakan Google Earth oleh tim
PPM. Guru mitra diminta untuk mengamati kegiatan demonstrasi yang dilakukan oleh tim PPM. Pada fase reproduksi, guru SD sebagai mitra diminta untuk mengulangi kembali kegiatan yang telah didemonstrasikan dengan cara praktik langsung dengan komputer. Setiap guru mitra telah dipersiapkan satu unit komputer/orang yang sudah terhubung dengan jaringan Internet. Pada fase motivasi, guru dilatih untuk meningkatkan kemampuannya serta membiasakan pelaksanaan pendidikan IPS dengan media ICT melalui program SIG dan Google Earth sehingga pembelajaran ini dapat terlaksana secara berkelanjutan.

Evaluasi kegiatan dilakukan selama proses, pada aspek pencapaian tujuan dan penyelenggaraan. Evaluasi proses dan hasil dilakukan dengan angket tanya jawab, dan observasi. Evaluasi saat pelaksanaan meliputi, keterlibatan dan kemampuan peserta setiap tahapan, yaitu :

(1) mengidentifikasi, lokasi Propinsi dan Kota Bengkulu dengan Virtual Globe Google Earth, (2) menyusun kerangka tulisan (outline), (3) mengumpulkan bahan-bahan, mengorganisasikan, dan mengonsep pembelajaran, (4) menulis hasil interpretasi peta Bengkulu hasil dari Google Earth yang diintegrasikan dengan kompetensi mata pelajaran IPS Kurikulum 2013.

(2) Indikator keberhasilan selama proses pelatihan dengan melihat:

a. Kemampuan guru-guru dalam pemahaman kegiatan teknis SIG dan menggunakan aplikasi Google Earth

b. Keterampilan guru-guru dalam menyusun modul belajar yang mengintegrasikan perangkat, media, dan aplikasi TIK dengan kompetensi mata pelajaran IPS 
SMP sesuai tuntutan Kurikulum 2013, dan kemampuan interpretasi informasi hasil dari Virtual Globe Google Earth.

c. Jumlah guru-guru yang mampu dengan baik dan secara terampil melakukan, mengoperasikan, dan menginterpretasi hasil geografis perangkat, media, dan aplikasi TIK untuk diintegrasikan dengan kompetensi mata pelajaran IPS SMP.

Pada saat pelaksanaan telah dilakukan pengumpulan data pretes untuk mengetahui pengetahuan awal guru mengenai SIG. Berdasarkan hasil pretes, dapat diketahui beberapa hal sebagai berikut:

a) Sebesar $67 \%$ responden menyatakan belum pernah menggunakan media ICT dalam pembelajaran IPS di SMP

b) Sebesar $79 \%$ responden menyatakan belum memanfaatkan media ICT dalam materi IPS yang menggunakan sumber belajar peta dan globe.

c) Sebesar $58 \%$ responden menyatakan belum pernah memberikan tugas pada siswa untuk mengkomunikasikan tugas mata pelajaran IPS dengan media ICT

d) Sebesar 67\% responden guru menyatakan belum pernah memberikan tugas pada siswa untuk mengakses dan mencari informasi mengenai peta

e) Sebesar $79 \%$ responden guru sama sekali belum mengetahui tentang Sistem Informasi Geografis

f) Sebesar 92\% responden guru menyatakan bahwa belum mengetahui aplikasi Sistem Informasi Geografis yang dapat terintegrasi ke dalam mata pelajaran IPS SMP

g) Sebesar $100 \%$ responden menyatakan bahwa sebagian besar guru IPS SMP belum mengetahui aplikasi program SIG yang dapat dipergunakan dalam pembelajaran IPS.

h) Sebesar $88 \%$ responden menyatakan bahwa SIG sangat diperlukan untuk mendukung dalam pembelajaran IPS di SMP

i) Sebesar $63 \%$ responden telah mempergunakan peta dan globe manual sebagai media pembelajaran IPS di kelas.

j) Sebesar $100 \%$ responden menyatakan belum pernah menggunakan media peta digital Google Earth dalam pembelajaran IPS untuk mendukung kurikulum 2013.

Hasil pretes menunjukkan bahwa 100\% semua guru IPS SMP belum pernah menggunakan media peta digital dan belum mengetahui aplikasi SIG dalam pembelajaran yang dapat mendukung implementasi kurikulum 2013. Separuh responden menyatakan hanya menggunakan media peta dan globe manual di kelas. Penggunaan media ini belum mengembangkan keterampilan kognitif dan penguasaan pengetahuan. Selain itu, hampir sebagian besar guru belum menggunakan media ICT baik dalam pembelajaran maupun penugasan mata pelajaran IPS SMP. Hal ini menunjukkan bahwa kemampuan ICT guru IPS di Kota Bengkulu masih sangat kurang. Seharusnya guru IPS telah menguasai teknologi perangkat keras dan perangkat lunak dalam proses belajarmengajarnya.

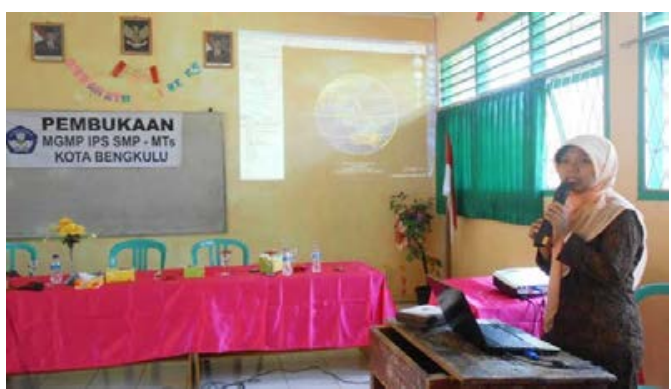

Tim menyampaikan sosialisasi kegiatan Gambar 1. Sosialisasi Kegiatan Sistem Informasi Geografis (SIG) Pada Rapat Tim MGMP Se-Kota Bengkulu 


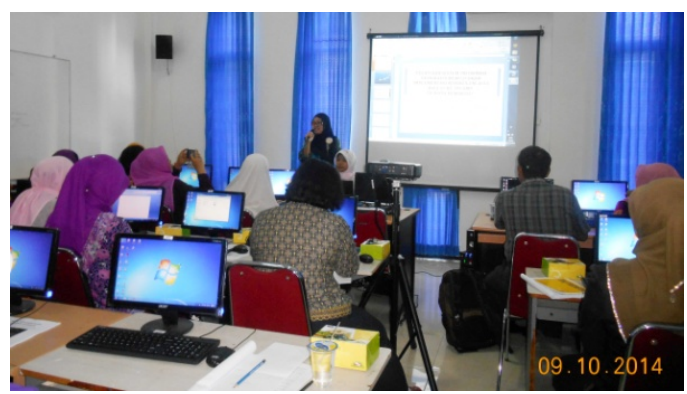

Ketua Tim membuka kegiatan

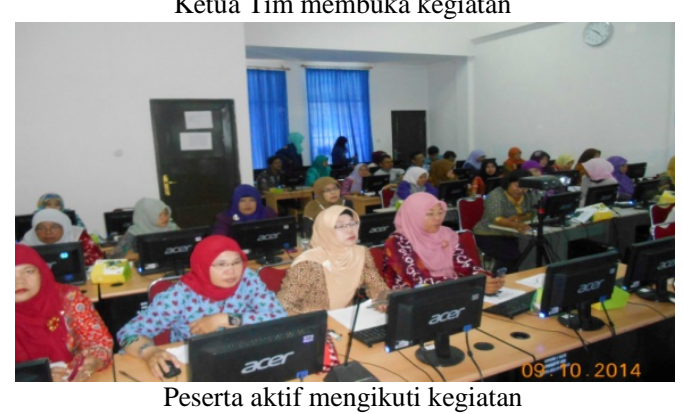

Gambar 2. Pelaksanaan Pelatihan Sistem Informasi Geografis (SIG) Untuk Mewujudkan Implementasi Kurikulum 2013 Bagi Guru IPS SMP Di Kota Bengkulu

Teknologi adalah sebuah alat yang dapat memperdalam pengetahuan dan membantu siswa agar menjadi lebih kreatif dalam memecahkan masalah. Program SIG dengan Google Earth ini memiliki banyak manfaat yaitu menstimulasikan keterlibatan pengguna secara aktif; (b) mencapai penguasaan dan pemecahan masalah bagi siswa yang lebih kreatif; (c) mendorong siswa dapat mengeksplorasi sendiri peta digital untuk memperoleh pengalaman belajar berkesan; dan (d) mendukung proses pembelajaran yang berpusat pada siswa dan berpusat pada pengetahuan. Potensi penggunaannya dapat maksimal bila didukung keterampilan teknis dan keterampilan perencanaan pembelajaran dari guru.

Melalui kegiatan ini telah menunjukkan peningkatan kemampuan guru. Penggunaan Google Earth sebagai peta digital dalam pembelajaran membuat proses belajar menjadi lebih interaktif. Selain itu pembelajaran yang menggunakan integrasi teknologi dalam mata pelajaran IPS SMP menjadikan pembelajaran lebih menarik dan dipahami. Interaksi dalam kelas juga mengkaitkan pengalaman langangung melalui visualisasi, karena visualisasi adalah cara yang baik dalam memahami dan meningkatkan pengetahuan yang lebih lama dalam ingatan dan lebih berkesan.

\section{KESIMPULAN DAN SARAN \\ akukan praktek}

Simpulan dari kegiatan ini, sebagai berikut:

(1) melalui program SIG dan Google Earth telah dapat meningkatkan pemahaman guru IPS SMP di Kota Bengkulu untuk mengintegrasikan mata pelajaran IPS dengan TIK dalam mengimplementasikan Kurikulum 2013;

(2) peningkatan kemampuan guru dalam menyusun pembelajaran yang mengintegrasikan perangkat, media, dan aplikasi TIK dengan kompetensi mata pelajaran IPS SMP; dan (3) peningkatan kapasitas guru IPS SMP di Kota Bengkulu dalam membaca dan memahami peta digital geografis dengan Google Earth.

Saran yang dapat diajukan yaitu: (1) Sekolah diharapkan dapat menerapkan pembelajaran menggunakan media interaktif seperti Google Earth untuk meningkatkan hasil belajar; (2) Guru IPS SMP disarankan untuk menggunakan media Google Earth; dan (3) kegiatan ini dapat berkelanjutan dengan mengembangkan media SIG dan Google Earth dalam pembelajaran IPA, PKn, Bahasa Indonesia, dan mata pelajaran lainnya.

\section{REFERENSI}

[1] Prahasta, Eddy, 2010, Sistem Informasi Geografi, Bandung: Penerbit Informatika.

[2] ESRI, 1997, ArcView GIS: Tutorial Disc, Enviromental Systems Research Institute Inc.

[3] Purwandari, Endina Putri, 2010, Analisis Topologi dan Populasi Penduduk Pemukiman Miskin menggunakan Teknologi Remote Sensing, Jurnal Magister Teknologi Informasi (MTI), Volume 6, No.1 April 2010, Jakarta: Universitas Indonesia. 
Jurnal Pseudocode, Volume III Nomor 1, Februari 2016, ISSN 2355 - 5920

[4] Kementerian Pendidikan dan Kebudayaan (Kemdikbud), 2013, Ilmu Pengetahuan Sosial SMP/MTs Kelas VII, Jakarta: Kementerian Pendidikan dan Kebudayaan.

[5] Sunarhadi, Amin., Dilahur, dan Priyono, 2007, Pelatihan Sistem Informasi Geografi Kepada Guru SMA/MA Se-Eks Karesidenan Surakarta, Warta, Vol 10, No.1, Maret 2007, hal. 25-35, Solo: Universitas Muhamadiyah Surakarta.

[6] Talip, Roslee dan Mohd Saifullah Md Sobri, 2013, Penggunaan Aplikasi Google Earth dalam meningkatkan Prestasi Pelajar Mata Pelajaran Geografi di Sekolah Menengah, Seminar Pendidikan Sejarah dan Geografi, 29-30 Agustus 2013. Malaysia: Universiti Malaysia Sabah. 